\title{
Developing the Forest Fire Danger Index for the Country Kazakhstan by Using Geospatial Techniques
}

\author{
K. V. S. Babu ${ }^{1 *}$, G. Kabdulova ${ }^{1}$, and G. Kabzhanova ${ }^{1}$ \\ ${ }^{1}$ The Joint-Stock Company, National Company, Kazakhstan Gharysh Sapary, Astana 010000, Kazakhstan
}

Received 19 November 2018; revised 28 February 2019; accepted 14 March 2019; published online 31 March 2019

\begin{abstract}
Forest fire is a major ecological disaster, which has economic, social and environmental impacts on humans and also causes the loss of biodiversity. Kazakhstan forests are more prone to fires due to the presence of coniferous forests and loss was enormous. There is a need of forest fire danger indices to estimate the potential fire danger so that fire officials effectively control the fires. Global forest fire danger indices require daily meteorological stations data as well as ground investigation data. But, there are less number of meteorological stations are available in Kazakhstan, hence, the satellite derived parameters were used to develop the fire danger index in this study. In this study, Static forest fire probability index was developed by using the SRTM DEM and MODIS TERRA and AQUA Land cover type product (MCD12Q1). Dynamic forest fire probability index was calculated by using the MODIS TERRA Land Surface Temperature (MOD11A1) and Surface reflectance (MOD09GA). Dynamic forest fire probability index has been developed from the parameters, i.e. LST, Normalized Multi-band Drought Index (NMDI), Visible Atmospheric Resistant Index (VARI) and Modified Normalized Difference Fire Index (MNDFI). Finally, Fire danger index was developed by adding both the static and dynamic probability indices and Fire hotspot data (MCD14) has been used for the validation of the index. Accuracy was ranging from $77.78 \%$ to $90.32 \%$ and the overall accuracy was $84.14 \%$. Developed Fire danger index was in operational, calculating by using MODIS Near Real Time datasets and uploading and updating every day in the website.
\end{abstract}

Keywords: MODIS, forest fire, fire danger index, dynamic forest fire probability index, static forest fire probability index

\section{Introduction}

Forest fires are considered as major disaster across the world to damage forest resources, environment (Roy, 2003). The term "fire hazard" described as phenomenon which can cause harm to the forest resources, humans and the environment due to fire (Bachmann and Allgower, 2001; Hardy, 2005). The term "fire danger" describes the probability that a fire can occur due to the natural causes and anthropogenic activities (Bachmann and Allgower, 2001; Hardy, 2005). The prediction of forest fire danger is essential for the fire management and strategic planning of forest protection. Forest fuel characteristics, terrain features as well as weather conditions are the main factors for the initiation and spread of forest fires (Abatzoglou and Kolden, 2013; Birch et al., 2015). The essential part of the strategic planning is to identify the fire potential danger zones i.e., sites where a forest fire most probable to start and from where, the fires can spread to other forest areas, at local level and sometimes at regional level (Jaiswal et al., 2002). There are four different approaches proposed to model the forest fire danger, some of them knowledge i.e., classify the fire danger variables using a numer-

${ }^{*}$ Corresponding author. Tel.: 789-520-8605; fax: +7 (7122) 24-88-61. E-mail address: sureshbabu.iiith@gmail.com (K. V. S. Babu).

ISSN: 2663-6859 print/2663-6867 online

(C) 2019 ISEIS All rights reserved. doi:10.3808/jeil.201900006 ical scale based on the weights, derived from the review of literature, experts' opinion, field-based observations and reclassify into a level of danger classes like Extreme, high, medium, and low (Chuvieco and Salas, 1996). 2. Multi-criterial based quantitative models i.e., here also models involve expert opinions, but they reduce the subjectivity when selecting the weights. This method though helps to make agreement among the experts when there is difference of opinions (Chen et al., 2001). 3. Statistical models (Chuvieco and Salas, 1996; Hernandez-Leal et al., 2006) i.e., they depend on the study area spatial characteristics. So, these models cannot be extrapolated to other areas. Linear regression, poison distribution and logistic regression are the examples of statistical models. This models also include neural network-based approaches. 4. Fire dispersion models i.e., fire spreading models such as Behave, FARSITE etc. 5. Physical models i.e., based on the scientific principles and extensive ground studies. Canadian Fire Weather Index (Van Wagner and Forest, 1987) and McArthur Fire Danger Rating (McArthur, 1967) are the examples of physical models.

Fire danger is often associated with numerical indices calculated based on different temporal scales like daily, weekly and monthly referring to the meteorological conditions that might lead to fire ignition and fire propagation (Allgöwer et al., 2003). Fire danger is defined as the result of both static (fuel and topographic characteristics) and variable (weather parameters) factors 
of fire environment triangle, that are affecting the initiation, propagation of fire (Chandler et al., 1983). Fire Danger Rating System is a Decision Support System which takes into consideration of all the factors (static and dynamic) responsible for fire danger and categorizing into different fire danger classes for issuing warnings to the public, fire officials to implement the precaution measures for controlling fires (Willis et al., 2001). Fire Danger Index is categorized into danger classes to provide a rating such as Low, Moderate, High, Very High, and Extreme (Matthews, 2009).

Most fire danger rating systems use only weather parameters in the calculation of danger index assuming the fuel, topography characteristics as constant. So, there is a possibility to use weather forecasts to predict the fire danger for a period of time ahead (McArthur, 1967; Van Wagner and Forest, 1987). The weather inputs are usually taken from a specific weather station which is broadly a representative of the area and then applied to the surrounding region. A well-known Forest Fire Danger indices are Australia's McArthur Forest Fire Danger Index (FFDI) (McArthur, 1967), Canadian Fire Weather Index (FWI) (Van Wagner and Forest, 1987), The US National Fire Danger Rating System (Deeming et al., 1977) and European Forest Fire Information System (Vilar et al., 2015) using across the world (Babu et al., 2016a). They are developed on the basis of their applicability to the country or area in which it is applied. These fire danger indices are different not only in terms of their spatial scale (local to regional scale) but also in terms of temporal scale (Daily, Weekly, and Monthly). Forest fire danger models like Canadian FWI approach has been adapted in many countries Argentina, USA and Alaska (Alexander and Cole, 2001; Taylor, 2006), Indonesia (De Groot et al., 2007), Malaysia (De Groot et al., 2007), Mexico (Lee et al., 2002), New Zealand (Alexander and Fogarty, 2002), Portugal (San-Miguel-Ayanz et al., 2003), Spain (Viegas et al., 1999) and Sweden (Granström, 2001) around the world for forecasting the fire danger on daily basis using automatic weather stations data. The difficulties to adapt FWI are insufficient weather stations to cover the forests of country Kazakhstan and lack of ground investigation data.

Therefore, remote sensing-based fire danger indices are developed in some countries as there is un-availability of sufficient number of meteorological stations. In those studies, satellite derived indices and parameters were used to estimate the fire danger. Commonly used indices are Normalized Difference Vegetation Index (NDVI) (Leblon et al., 2007), Enhanced vegetation index (EVI) (Bisquert et al., 2012; Bisquert et al., 2014), Vegetation Index green (VI green), Global Vegetation Moisture Index (GVMI) (Sow et al., 2013), Visible Atmospheric Resistant Index (VARI) (Schneider et al., 2008; Babu and Agarwal, 2014), Normalized Multiband Drought Index (NMDI) (Wang et al., 2008; Babu and Agarwal, 2014), Normalized Difference Water Index (NDWI) (Stow et al., 2005). The live fuel moisture conditions were measured as a combination of NDVI and Ts (Chuvieco et al., 2002) or a combination of vegetation greenness indices such as NDVI, EVI, VIgreen, VARI; wetness indices such as NDWI (Peterson et al., 2008). The dead fuel moisture conditions were determined by combing the weather variables such as air Ta and RH, derived from the MSG-SEVIRI (Nieto et al., 2011). Remote sensing-based fire danger indices are having higher spatial resolution and more accurately predict the fire danger as compared to the automatic weather stations-based fire danger indices. Based on the above discussion, remote sensing-based parameters are useful to develop the fire danger index with better spatial resolution in the regions where, the sufficient meteorological stations are not available. Therefore, main objecttive of this study is to develop the fire danger index for the country Kazakhstan using remote sensing based parameters.

The country Kazakhstan, ninth largest country in terms of area in the world, more prone to forest fires every year during the period of June to Sept months, but, operational fire danger system does not exist to predict the forest fires. A very few studies are available related to forest fires of this country. The objective of our study is to develop fire danger index for the Kazakhstan and fire danger maps will be uploaded into the website for the easy access to forest managers, officials as well as the general public. In this study, satellite derived datasets have been used to develop the fire danger index as the limited number of installed meteorological stations in and around forests.

\section{Satellite Datasets}

MODIS (Moderate Resolution Imaging Spectroradiometer) is a sensor mounted on board NASA's TERRA and AQUA satellites and it consists of 36 spectral bands ranging from $250 \mathrm{~m}$ to $1 \mathrm{~km}$ spatial resolution. NASA provides the different temporal MODIS data products made it freely available and can be downloaded from the Earthdata website (https://earthdata.nasa.gov/). The NASA Shuttle Radar Topographic Mission (SRTM) provides the digital elevation data (DEM) for the entire earth and data is freely available. SRTM DEM data for the study area was downloaded from the USGS Earth Explorer website (https:// earthexplorer.usgs.gov/). Table 1 shows the daily satellite datasets used in this study.

Table 1. Satellite Datasets

\begin{tabular}{llll}
\hline Name of Datasets & Product ID & $\begin{array}{l}\text { Spatial } \\
\text { Resolution }\end{array}$ & $\begin{array}{l}\text { Temporal } \\
\text { Resolution }\end{array}$ \\
\hline $\begin{array}{l}\text { SRTM DEM } \\
\text { Land Surface }\end{array}$ & SRTM & $1 \mathrm{~km}$ & - \\
$\begin{array}{l}\text { Temperature } \\
\text { Land cover type }\end{array}$ & MOD11A1 & $1 \mathrm{~km}$ & Daily \\
$\begin{array}{l}\text { Surface Reflectance } \\
\text { Fire and Thermal } \\
\text { Anomalies }\end{array}$ & MOD09GA & $500 \mathrm{~m}$ & Yearly \\
\hline
\end{tabular}

The MOD09GA provides the surface reflectance at $500 \mathrm{~m}$ pixel resolution, consists of seven bands (Bands 1 to 7). The MOD11A1 products provide the land surface temperature and emissivity values, produced daily at $1 \mathrm{~km}$ spatial resolution (LPDAAC). The product MCD12Q1 is a global land cover annual product of $500 \mathrm{~m}$ spatial resolution, it provides the five land cover schemes, in which IGBP classified scheme was used in this study. Forest fire hotspots from 2012 to 2016 are downloaded from 
the NASA Fire Information for Resource Management System (FIRMS) website. Human influence index (HII) of $1 \mathrm{~km}$ grid was downloaded from the NASA Socioeconomic Data and Applications Center (SEDAC) website and is expressed as in percentage, ranging from 0 to 100 . The fire and thermal anomaly product MCD14 have been used for the validation of the developed forest fire danger index.

\section{Study Area}

The study area is Kazakhstan, largest of the Central Asian states and it has boarders with Russia, China, and the Central Asian countries of Kyrgyzstan, Uzbekistan, and Turkmenistan. Kazakhstan is the world's largest landlocked country, and the ninth largest in the world, with an area of $2,724,900 \mathrm{~km}^{2}$, and the total forest area is $125,345 \mathrm{~km}^{2}$, i.e., $4.6 \%$ of the total land cover of the country. Forest fires are common feature in this country due to the extreme weather conditions, characterized by hot and dry summers (June to September), therefore increase in the incidents of forest fires. As per the news article, five people lost their lives in the year 2010 due to the forest fires (IOL,2010). According to the Ministry of Emergency Situations of Kazakhstan, the forest fires were increased by $41 \%$ in the year 2015 and 39 $\mathrm{km}^{2}$ of forests burnt causing a loss of 370,802 US dollars (Kazakhstan International Security Exhibition, 2018). Operational fire danger system has not been developed to predict the fire danger in this country and very few studies on forest fires have been published despite the damage caused by forest fires. Therefore, fire danger index is necessary for the country Kazakhstan to manage the forest fires efficiently.

\section{Methodology}

The Forest Fire Danger Index has been developed from the static factors such as forest fuel characteristics, terrain characteristics and as well as the dynamic factors like weather-based parameters. Figure 1 shows the flow chart showing the methodology to develop forest fire danger index. Static forest fire probability index is calculated from the datasets such as MODIS TERRA and AQUA landcover type, SRTM GDEM as well as from the human influence index. Dynamic forest fire probability index is generated from the parameters Land Surface Temperature (LST), Normalized Multi-band Drought Index (NMDI), Visible Atmospheric Resistant Index (VARI) and Modified Normalized Difference Fire Index (MNDFI), which are derived from the MODIS TERRA satellite datasets. The parameters NMDI is useful for estimating the drought condition, VARI is for estimating the relative greenness whereas, MNDFI is for identifying the higher temperatures as compared with the surroundings.

\subsection{Static Forest Fire Probability Index (SFFPI)}

First step is to develop the static forest fire probability index from the static parameters of the fire environment triangle. Fire environment triangle consists of 3 basic components i.e., fuel, topography, and weather, in which weather component is dynamic whereas the fuel and topography are static in nature (Roy et al., 2012). Topography (e.g., elevation, slope, aspect, and complexity) influences fire behavior directly, with rate of fire spread is higher on higher steeper slopes as compared with the lower ones (Rothermel, 1972). Topography is also one of the most important factors in predicting fire spreading potential (Taylor and Alexander, 2000; Flannigan et al., 2000). In this study, topographic

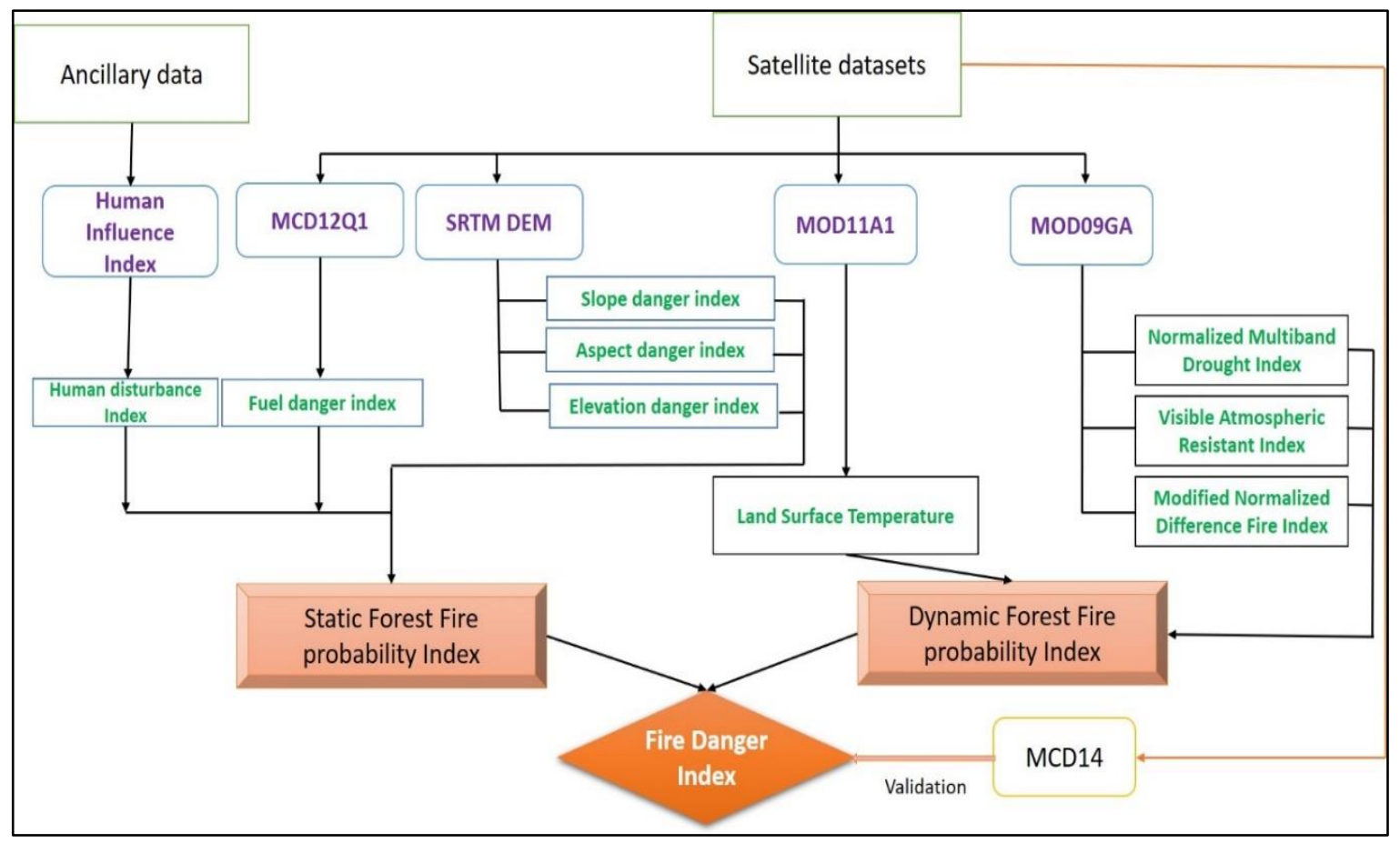

Figure 1. Schematic diagram shows the developing of Forest Fire danger index. 
K. V. S. Babu et al. / Journal of Environmental Informatics Letters 1(1) 48-59 (2019)

Table 2. Total Number of Fires Fell in Different Slope Ranges and Danger Classes

\begin{tabular}{|c|c|c|c|c|c|c|c|}
\hline \multirow{2}{*}{$\begin{array}{l}\text { Slope } \\
\text { Ranges }\end{array}$} & \multicolumn{5}{|l|}{ Year } & \multirow{2}{*}{$\begin{array}{l}\text { Percentage } \\
\text { mean }\end{array}$} & \multirow{2}{*}{$\begin{array}{l}\text { Danger } \\
\text { class }\end{array}$} \\
\hline & 2012 & 2013 & 2014 & 2015 & 2016 & & \\
\hline $0-20$ & 36 & 4 & 28 & 30 & 18 & 0.09 & No danger \\
\hline $20-40$ & 190 & 36 & 102 & 189 & 62 & 0.45 & No danger \\
\hline $40-60$ & 2796 & 865 & 1148 & 1876 & 658 & 6.14 & Low \\
\hline $60-80$ & 8164 & 3454 & 7529 & 7811 & 4514 & 27.25 & Moderate \\
\hline$>80$ & 19773 & 6535 & 20292 & 23904 & 10198 & 66.06 & Very high \\
\hline
\end{tabular}

Table 3. Danger Classes are Assigned to Elevation Ranges

\begin{tabular}{|c|c|c|c|c|c|c|c|}
\hline \multirow{2}{*}{$\begin{array}{l}\text { Elevation } \\
\text { Ranges }\end{array}$} & \multicolumn{5}{|l|}{ Year } & \multirow{2}{*}{$\begin{array}{l}\text { Percentage } \\
\text { mean }\end{array}$} & \multirow{2}{*}{ Danger class } \\
\hline & 2012 & 2013 & 2014 & 2015 & 2016 & & \\
\hline$<500$ & 26950 & 8048 & 20773 & 23178 & 12165 & 75.92 & Very high \\
\hline $500-1000$ & 3361 & 2404 & 6548 & 8252 & 2900 & 19.72 & Moderate \\
\hline $1000-1500$ & 420 & 337 & 1354 & 2295 & 280 & 3.54 & Low \\
\hline $1500-2000$ & 109 & 79 & 226 & 77 & 89 & 0.53 & No danger \\
\hline $2000-2500$ & 85 & 22 & 170 & 16 & 4 & 0.23 & No danger \\
\hline $2500-5000$ & 36 & 3 & 25 & 2 & 0 & 0.05 & No danger \\
\hline$>5000$ & 8 & 1 & 1 & 1 & 0 & 0.01 & No danger \\
\hline
\end{tabular}

Table 4. Total Number of Fires Fell in Elevation Ranges

\begin{tabular}{|c|c|c|c|c|c|c|c|}
\hline \multirow{2}{*}{$\begin{array}{l}\text { Aspect } \\
\text { classes }\end{array}$} & \multicolumn{5}{|l|}{ Year } & \multirow{2}{*}{$\begin{array}{l}\text { Percentage } \\
\text { mean }\end{array}$} & \multirow{2}{*}{ Danger class } \\
\hline & 2012 & 2013 & 2014 & 2015 & 2016 & & \\
\hline Flat & 236 & 40 & 128 & 230 & 68 & 0.537939 & No danger \\
\hline North & 2785 & 778 & 2523 & 2991 & 1500 & 8.673166 & Moderate \\
\hline Northeast & 3652 & 1241 & 3422 & 3960 & 1682 & 11.50986 & High \\
\hline East & 2603 & 808 & 2421 & 2796 & 1208 & 8.046988 & Moderate \\
\hline Southeast & 3598 & 1280 & 3539 & 4476 & 2203 & 12.60711 & Very High \\
\hline South & 3579 & 1095 & 4229 & 4986 & 2134 & 12.94170 & Very High \\
\hline Southwest & 3903 & 1761 & 3709 & 4141 & 1877 & 13.18354 & Very High \\
\hline west & 3443 & 1321 & 2784 & 3417 & 1429 & 10.43433 & Moderate \\
\hline Northwest & 4823 & 1816 & 3999 & 4265 & 1969 & 14.27051 & Very High \\
\hline North & 2347 & 754 & 2343 & 2557 & 1368 & 7.794851 & Moderate \\
\hline
\end{tabular}

danger indices such as slope, aspect, and elevation danger indices generated from the SRTM elevation data. First, DEM data was resampled into $1 \mathrm{~km}$ before generating the danger indices to maintain the same resolution as dynamic danger indices. The danger indices were generated based on the historical fire hotspot information from the years 2012 to 2016 and the detailed procedure is explained in below.

\subsubsection{Slope Danger Index}

Slope map was generated from the SRTM dem data using the spatial analyst tools of ArcMap software. Slope is an important factor in fire danger models because fire travels upper slope faster than down slopes (Chuvieco and Congalton, 1989; Jaiswal et al., 2002). Forest fire hotspots from the 2012 to 2016 overlaid on the slope map to count the number of fire points in different slope intervals in each year. Percentage of fires fell in each slope intervals and mean percentage was calculated to measure the slope intervals, which are more vulnerable to fire spread. Table 2 shows the total number of forest fire hotspots fell in different ranges of slope and danger classes are assigned on the basis of percentage mean. Danger classes are categorized into 5 classes: No danger, Low, Moderate, High, and Very high.

\subsubsection{Elevation Danger Index}

The variable elevation is also an important parameter in fire danger models due to its influence on the temperature variations as well as the precipitation (Chuvieco and Congalton, 1989; Jaiswal et al., 2002). The elevation ranges were categorized into 7 classes and Table 3 shows the total number of fire incidents in different elevation ranges of the country.

The number of fires were low in the elevation ranges above 2,500 msl while, the number of fires were very high in the elevation ranges below $500 \mathrm{msl}$ as observed from the Table 2 . The danger classes were assigned to different elevation ranges based on the mean value as shown in the Table 3 .

\subsubsection{Aspect Danger Index}

Aspect is an important parameter as it influences the precipitation and incoming solar radiation in the study site (Chuvieco 
Table 5. Total Number of Fires in Each Forest Type

\begin{tabular}{|c|c|c|c|c|c|c|c|}
\hline \multirow{2}{*}{ Class name } & \multicolumn{5}{|c|}{ Forest type } & \multirow{2}{*}{$\begin{array}{l}\text { Percentage } \\
\text { mean }\end{array}$} & \multirow{2}{*}{$\begin{array}{l}\text { Danger } \\
\text { classes }\end{array}$} \\
\hline & 2012 & 2013 & 2014 & 2015 & 2016 & & \\
\hline Evergreen needle leaf forests & 24 & 10 & 9 & 12 & 27 & 0.09 & No fire \\
\hline Evergreen broadleaf forests & 0 & 0 & 0 & 0 & 0 & 0 & No fire \\
\hline Deciduous Needleleaf forests & 32 & 23 & 7 & 12 & 4 & 0.05 & No fire \\
\hline Deciduous broadleaf forests & 2 & 3 & 1 & 1 & 2 & 0.01 & No fire \\
\hline Mixed forests & 62 & 21 & 19 & 30 & 18 & 0.12 & Low \\
\hline Closed scrublands & 5 & 3 & 0 & 3 & 3 & 0.01 & No fire \\
\hline Open scrublands & 132 & 91 & 78 & 61 & 43 & 0.32 & Low \\
\hline Woody savannas & 94 & 59 & 37 & 14 & 15 & 0.16 & No fire \\
\hline Savannas & 5 & 16 & 15 & 1 & 4 & 0.03 & No fire \\
\hline Grasslands & 25149 & 40649 & 16263 & 24480 & 9279 & 82.19 & Very high \\
\hline Permanent wetlands & 201 & 49 & 14 & 149 & 72 & 0.39 & - \\
\hline Croplands & 5291 & 6208 & 2163 & 5453 & 1068 & 13.59 & High \\
\hline Urban and built-up lands & 244 & 270 & 275 & 254 & 204 & 1.10 & Moderate \\
\hline $\begin{array}{l}\text { Cropland/natural vegetation } \\
\text { mosaics }\end{array}$ & 750 & 824 & 347 & 375 & 89 & 1.57 & Moderate \\
\hline Snow and ice & 0 & 3 & 1 & 0 & 0 & 0 & No fire \\
\hline Barren & 48 & 64 & 50 & 177 & 89 & 0.39 & No fire \\
\hline
\end{tabular}

and Congalton, 1989; Jaiswal et al., 2002). Generally, southern slopes receive more intense of solar radiation as compared with the northern slopes. Aspect map was generated by using the spatial analyst tools in ArcMap software. Table 4 shows the number of fire hotspots and weights were assigned in similar way as based on the percentage mean.

\subsubsection{Fuel Danger Index}

MODIS Terra + Aqua Land Cover Type Yearly L3 Global $500 \mathrm{~m}$ SIN Grid product (MCD12Q1) consists of five classification schemes, which was derived from MODIS TERRA and AQUA satellite one year observed data. The primary land cover scheme i.e., International Geosphere Biosphere Programme (IGBP), categorized into 17 land cover classes and was extracted by using the HEG tool software. Table 5 shows the total number of fire incidents in different land cover types for the years 2012 to 2016 and assigned danger classes.

\subsubsection{Human Disturbance Index}

The Human influence index (HII) has been used in this study for the measure of human disturbances in forest lands of Kazakhstan. This index is a measure of direct influence of humans on global ecosystems, generated from the best available datasets like settlements, accessibility and landuse and landcover changes (https:// sedac.uservoice.com). HII of $1 \mathrm{~km}$ grid was downloaded from the NASA Socioeconomic Data and Applications Center (SEDAC) website and is expressed as in percentage, ranging from 0 to 100 . Forest fire hotspot data of 2012 to 2016 have been overlaid on the human influence index to generate the human disturbance index. If the human influence index value is above the 60 , there is large number of fire incidents during this period. The danger indices i.e., aspect danger index, slope danger index, elevation danger index, fuel danger index, human disturbance index were shown in the Figure 2.
The Static forest fire probability index was generated by combining the above generated individual indices i.e., slope danger index, elevation danger index, aspect danger index, human disturbance index and fuel danger index. The SFFPI consists of values from 1 to 25 was categorized into 5 classes i.e., no fire $(\leq 5)$, low $(6 \sim 10)$, moderate $(11 \sim 15)$, high $(16 \sim 20)$, and very high $(>20)$ fire danger classes and the generated index was shown in Figure 3.

\subsection{Dynamic Forest Fire Probability Index (DFFPI)}

In general, dynamic forest fire danger indices are calculated from the meteorological stations data, for example, Canadian Forest Fire Danger Rating System (Van Wagner and Forest, 1987), McArthur Forest Fire Danger Index (McArthur, 1967) and US National Fire Danger Rating System (Van Nest and Alexander, 1999). But there are very few meteorological stations are available in and around Kazakhstan forests, so, the satellite derived datasets were used to calculate the Dynamic fire probability index in this study. The MODIS TERRA datasets MOD09A1 and MOD11A2 were downloaded from the Earth data website for the year 2017 during the fire season of the country Kazakhstan i.e., June 1 to Nov 15. The country covers in the 6 MODIS tiles i.e., h21v03, h21v04, h22v03, h22v04, h23v03 and h23v04. The datasets are in hierarchical data format (hdf) and have to be convert into tiff format and mosaicked to get one image for the country. HEG tool software enables users to read HDF files, convert and mosaic the different tile data. MODIS bands from 1 to 7 were extracted by using HEG tools software and multiplied by a scale factor 0.0001 to get the surface reflectance. The calculation of Dynamic Forest Fire Probability Index was explained in below.

\subsubsection{Normalized Multiband Drought Index (NMDI)}

Drought factor is considered as one of the important factors 
in the fire danger analysis as it affects the vegetation fuel, litter to be drier so that there is always a chance of fire ignition. Normalized Multiband Drought Index has been used as a proxy for drought factor in this study. The Normalized Multi-Band Drought Index (NMDI) is useful to measure the amount of water content present in soil and vegetation of the ground surface (Wang and $\mathrm{Qu}, 2007)$. Fire pixels have the lowest values than other pixels
(Wang and Qu, 2009; Babu et al., 2017) and NMDI is calculated by using spectral bands 2, 6 and 7 by using Equation 1 (Wang et al., 2008):

$$
N D M I=\frac{\text { Band } 2-(\text { Band } 6-\text { Band } 7)}{\text { Band } 2+(\text { Band } 6-\text { Band } 7)}
$$

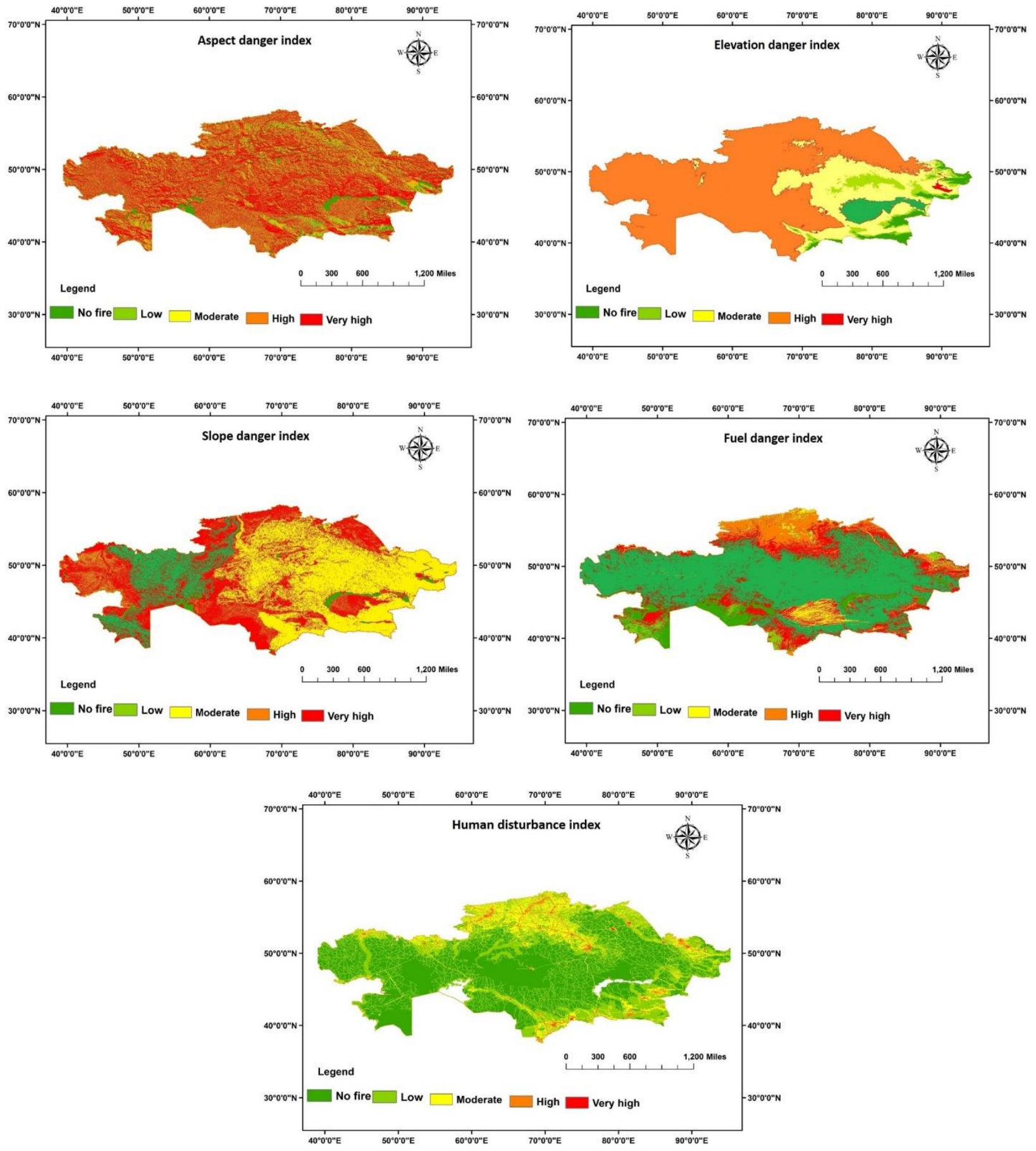

Figure 2. Static fire danger indices. 


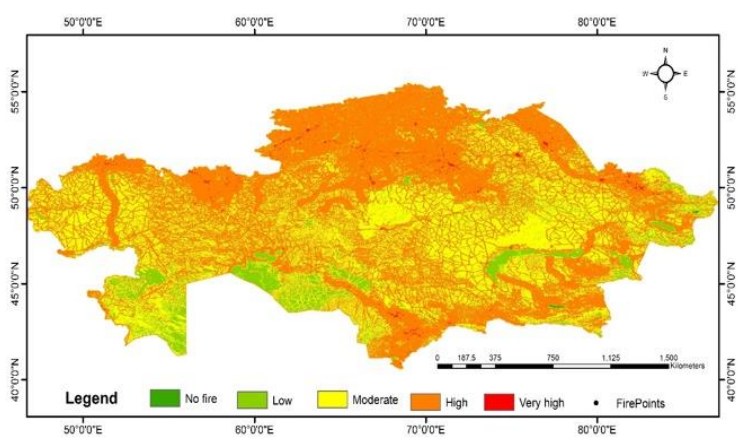

Figure 3. Static forest fire probability index.

\subsubsection{Visible Atmospheric Resistant Index (VARI)}

Visible Atmospheric Resistant Index (VARI) is a greenness index and is minimally sensitive to atmospheric effects and was developed for estimating green vegetation fraction, which is used to determine the relative greenness in the vegetation (Gitelson et al., 2002). VARI is calculated by using the Equation (2) using Spectral reflectance bands 1,3 and 4 :

$$
V A R I=\frac{\text { Band } 4-\text { Band } 1}{(\text { Band } 4+\text { Band } 1-\text { Band } 3)}
$$

\subsubsection{Modified Normalized Difference Fire Index (MNDFI)}

Modified Normalized Difference Fire Index (MNDFI) was used in this study to determine whether the pixel has higher temperature or not as compared with the surrounding pixels (Park et al., 2006; Babu et al., 2016a). MNDFI can be determined from the following formula (Vermote et al., 2002; EijiNunohiro et al., 2007; Babu et al., 2016a) and these have values are ranging from -1 to 1 :

$$
M N D F I=\left[\frac{\text { MODISBand } 7-\text { MODISBand } 2-0.05}{\text { MODISBand } 7+\text { MODISBand } 2+0.05}\right]
$$

\subsubsection{Land Surface Temperature (LST)}

Land surface temperature is a most important factor in fire danger estimation as it influences the moisture condition in veg-

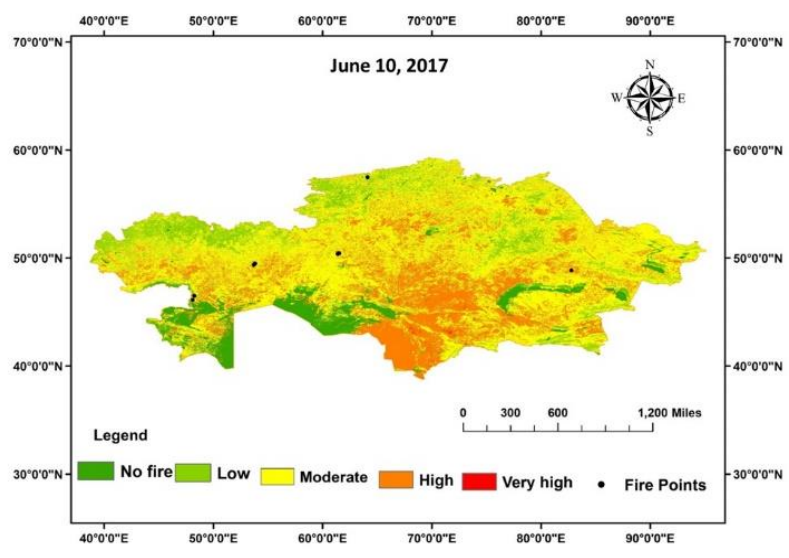

etation. It is widely used by several researchers in estimating the fire danger conditions (Bisquert et al., 2012; Chowdhury and Hassan, 2015). Land Surface Temperature can be derived from the MODIS TERRA dataset MOD11A2 and the derived LST product was multiplied by a scale factor of 0.02 to get the LST values in Kelvin scale.

\subsubsection{Threshold Conditions}

After calculating all the above mentioned intermediate indices and parameters i.e. LST, MNDFI, VARI and NMDI, threshold conditions were applied on these to categorize into five classes i.e., no fire, low, moderate, high and very high fire danger classes. The threshold conditions were obtained after analyzing all the above-mentioned parameters on the basis of fire occurrences and is shown in the Table 6.

Now, four parameters LST, NMDI, VARI and MNDFI were reclassified into 1 to 5 classes based on the pixel values and these classified maps were added to generate the Dynamic Forest Fire Probability Index (DFFPI) for the corresponding dates and The DFFPI consists of values from 4 to 20 .

Table 6. Threshold Conditions

\begin{tabular}{lllll}
\hline \multirow{2}{*}{ Danger classes } & \multicolumn{4}{c}{ Parameters and indices } \\
\cline { 2 - 5 } & LST & NMDI & VARI & MNDFI \\
\hline No fire (1) & $<295$ & $>0.20$ & $>1$ & $>0.50$ \\
Low (2) & 296 to & -0.11 to & 0.10 to & 0.20 to \\
& 305 & 0.20 & 1 & 0.50 \\
Moderate (3) & 306 to & -0.11 to & -0.15 to & 0 to 0.20 \\
& 315 & -0.01 & 0.10 & \\
High (4) & 316 to & -0.5 to & -0.40 to & -0.12 to \\
Very high (5) & 320 & -0.11 & -0.15 & -0.01 \\
\hline
\end{tabular}

Table 7. FDR Index Value Ranges

\begin{tabular}{lll}
\hline S. No. & Danger class & Value \\
\hline 1 & No fire & $\leq 16$ \\
2 & Low & $17 \sim 24$ \\
3 & Moderate & $25 \sim 31$ \\
4 & High & $32 \sim 39$ \\
5 & Very high & $>39$ \\
\hline
\end{tabular}

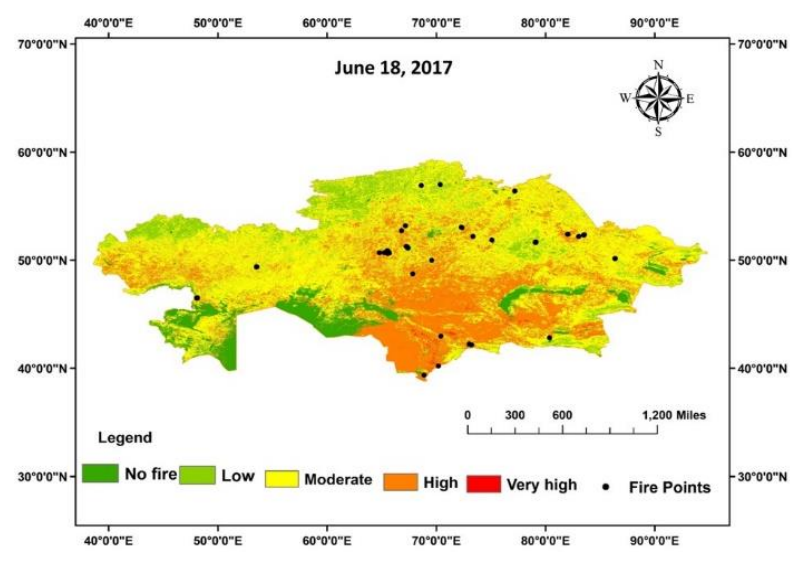



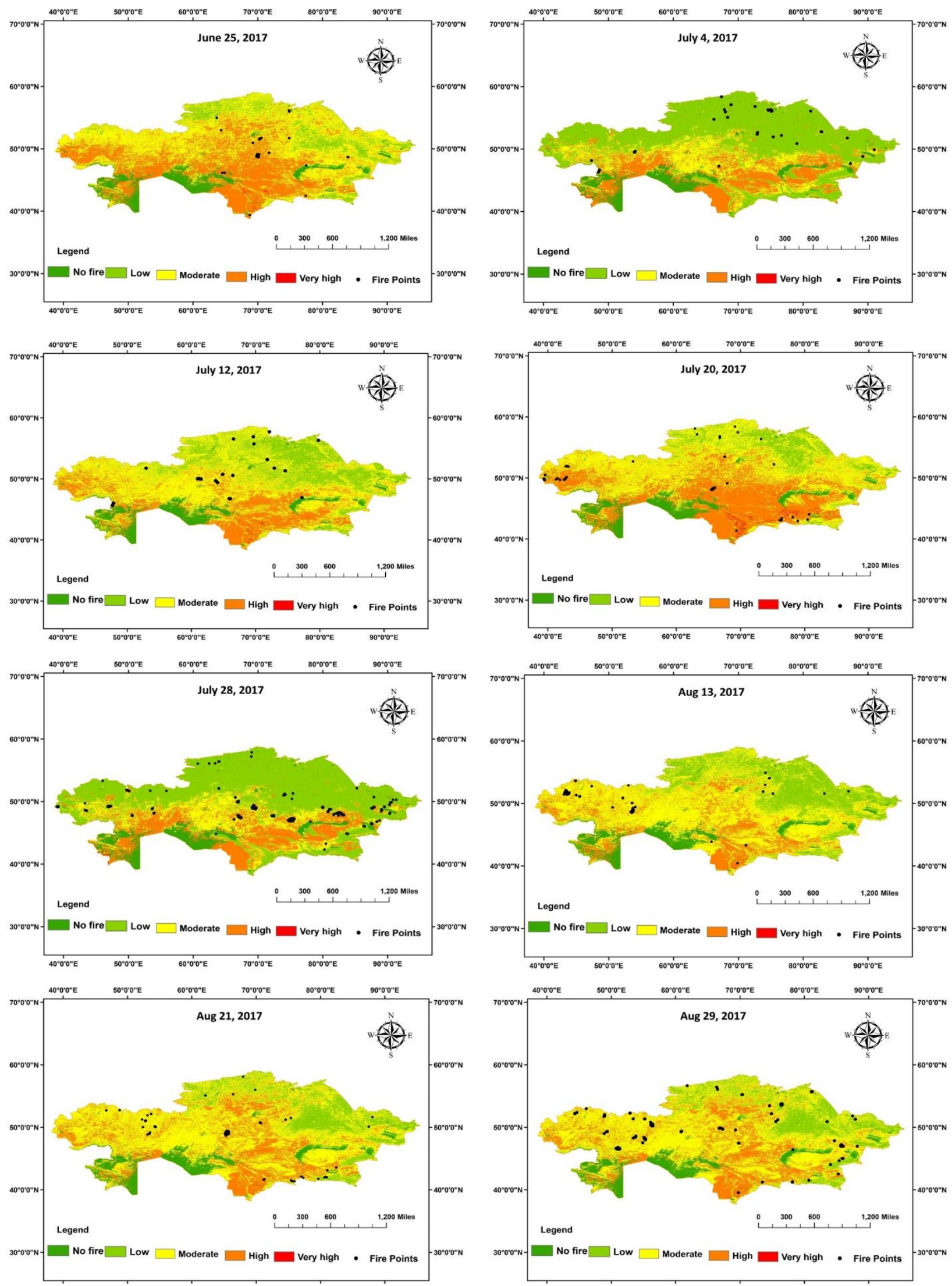

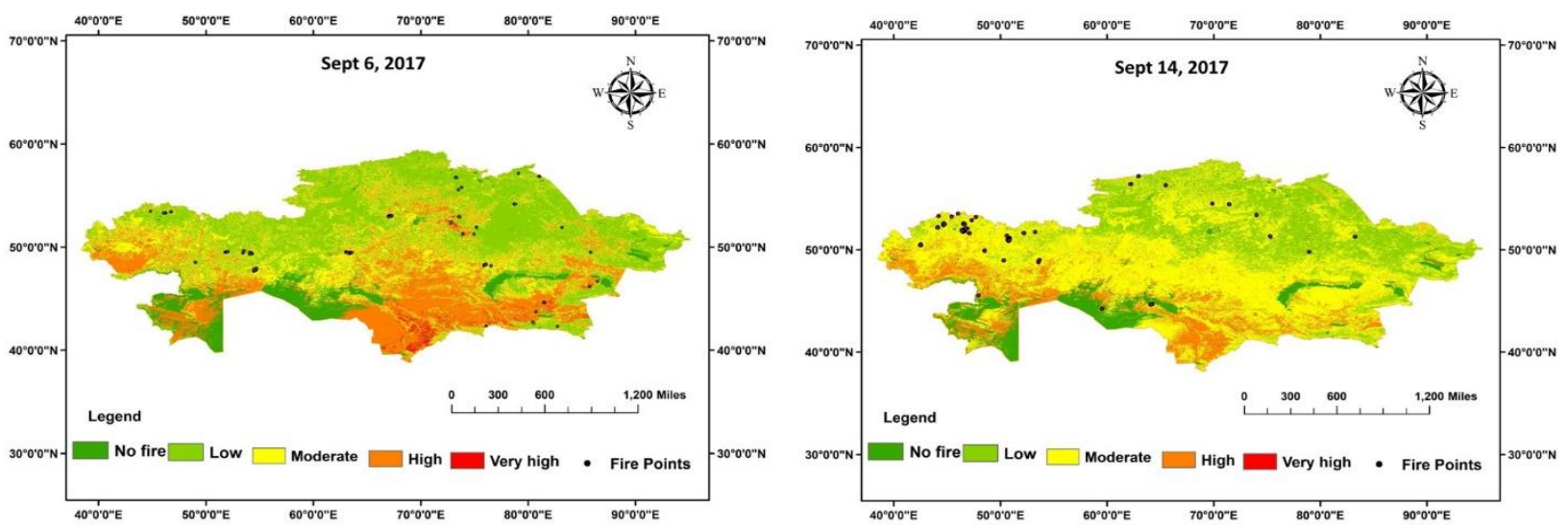

Figure 4. Fire danger index maps overlaid with fire hotspots on the corresponding dates.

\subsection{Fire Danger Index}

The static forest fire probability index is a constant for the study area and dynamic forest fire probability index was calculated for each individual day by using the MODIS TERRA satellite datasets MOD09A1 and MOD11A2. Fire danger index was calculated by adding both the static and adding forest fire probability index and was classified into 5 classes (Table 7).

\section{Results and Discussions}

Fire Danger Index maps were generated on selected dates during the fire season of Kazakhstan i.e., June 10, 2017; June 18, 2017; June 26; July 4; July 12; July 20; July 28; Aug 13, 2017; Aug 21, 2017 and September 14, 2017. The generated fire danger index maps were overlaid with corresponding fire hotspots to estimate the accuracy of the developed fire danger index. Several studies used MODIS TERRA and AQUA active fire hotspots for validating the fire danger indices as a proxy for the actual occurrence of fires across the world (Chuvieco et al., 2008; Vadrevu et al., 2009; Maeda et al., 2011; Adab et al., 2013; Chowdhury et al., 2015; Babu et al., 2016a, b). Figure 4 showing the fire danger maps overlaid with active fire hotspots on the corresponding dates.

For the accuracy estimation of individual fire danger maps, we assumed that the fires, that are fell in the high and very high fire danger classes were exactly identified by the index and remaining are not (Babu et al., 2016a). For the simplification, the five fire danger classes were merged into two classes i.e., no fire danger, low \& moderate; high and very high fire danger. The accuracy was defined as the ratio of number of fires fell in high and very high fire danger classes to the total number of fire incidents on that day (Babu et al., 2016a). Table 8 shows the accuracies of fire danger maps on selected dates of 2017 and accuracies are ranging from $77.78 \%$ to $90.32 \%$ and the overall accuracy is around $84.14 \%$.

The fire danger index shows a reasonable accuracy of $84.14 \%$ during the fire season of 2017 over the country Kazakhstan and tested for the years 2015 and 2016 fire season, estimated accuracy was around $85.46 \%$ and $87.65 \%$ respectively. Therefore, the developed fire danger index was accurately predicting the fire occurrences in the study area. Now, we are implementing the fire danger index for the fire prediction by using the near real time MODIS TERRA datasets. MODIS TERRA NRT datasets such as MOD09GA and MOD11_L2, which can be available for download from the ftp server after one hour of the satellite over-pass (ftp://nrt3.modaps.eosdis.nasa.gov/). The generated fire danger maps have been uploading everyday into our website (http://forest.gharysh.kz/). The fire danger maps can be accessed by the forest officials, fire managers as well as the registered public users for quick action to suppress the forest fires. Figure $5 \mathrm{a}, \mathrm{b}$ and $\mathrm{c}$ show the fire danger maps generated on the dates July 10, 2018; July 9, 2018 and July 8, 2018 and overlaid with the corresponding active fire hotspots.

Table 8. Accuracy of the Fire Danger Index

\begin{tabular}{lllll}
\hline \multirow{2}{*}{ S. No. } & Date & \multicolumn{2}{l}{ No. of fire incidents } & $\begin{array}{l}\text { Accuracy } \\
(\%)\end{array}$ \\
\cline { 3 - 5 } & & $\begin{array}{l}\text { No + Low }+ \\
\text { Moderate }\end{array}$ & $\begin{array}{l}\text { High }+ \\
\text { Very High }\end{array}$ & \\
\hline 1 & $2-06-17$ & 2 & 7 & 77.78 \\
2 & $18-06-17$ & 1 & 6 & 90.32 \\
3 & $26-06-17$ & 3 & 18 & 85.71 \\
4 & $4-07-17$ & 6 & 21 & 77.78 \\
5 & $12-07-17$ & 3 & 17 & 85.00 \\
6 & $20-07-17$ & 5 & 33 & 86.84 \\
7 & $28-07-17$ & 12 & 79 & 86.81 \\
8 & $13-08-17$ & 5 & 27 & 84.37 \\
9 & $21-08-17$ & 5 & 31 & 86.11 \\
10 & $14-09-17$ & 6 & 25 & 80.64 \\
\hline
\end{tabular}

Thus, fire danger index was successfully developed for the country Kazakhstan by using satellite derived parameters and the fire danger system is in operational now to predict the fire danger. The fire danger maps have been generated and up-dated in each day by using the MODIS TERRA NRT satellite datasets in the website. 
(a) Fire danger map of 10, July 2018 uploaded into the website.

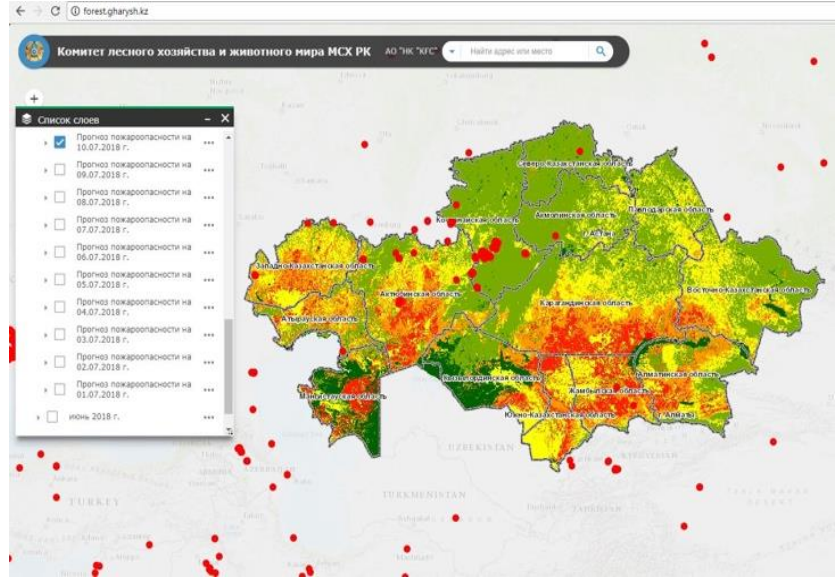

(b) Fire danger map of 9, July 2018 uploaded into the website.

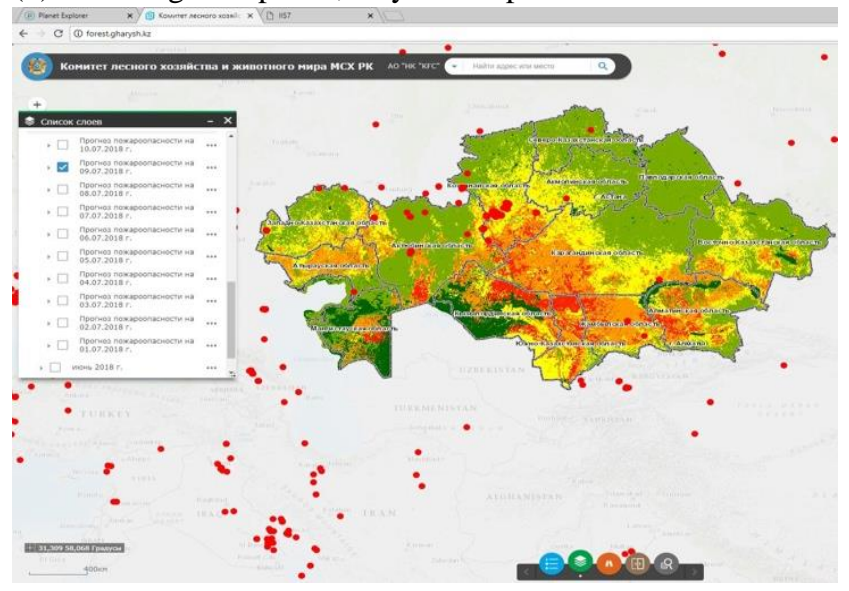

(c) Fire danger map of 8, July 2018 uploaded into the website.

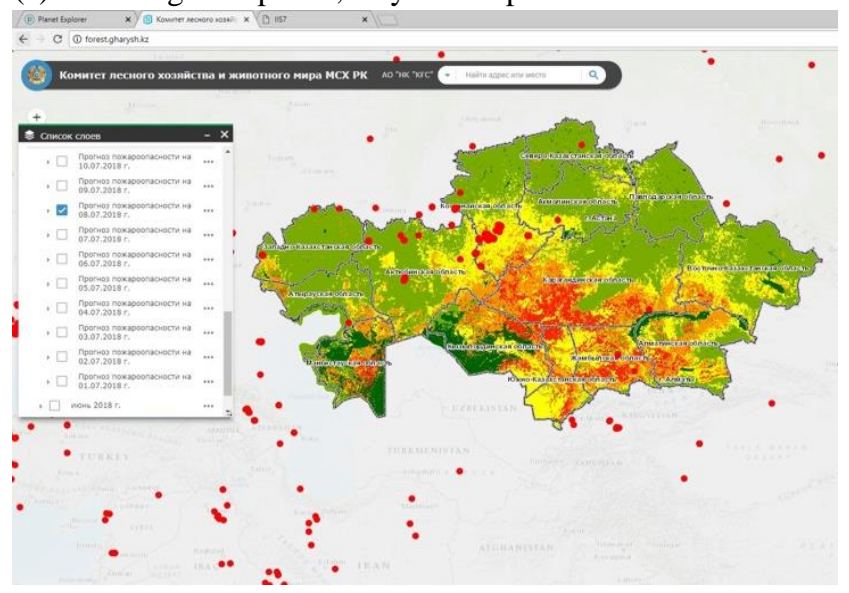

Figure 5. Fire danger map uploaded into the website: (a) 10, July 2018, (b) 9, July 2018, (c) 8, July 2018.

\section{Conclusions}

In this study, we developed the Fire danger index on the basis of static factors (Terrain properties, type of forest type), dynamic (satellite derived surface temperature, drought factors etc.) and also human disturbance index. Static forest fire probability index (SFFPI) was developed from the SRTM DEM, MODIS TERRA and AQUA landcover type product (MCD12Q1) and human influence index. The slope danger index, aspect danger index, elevation danger index, fuel danger index and human danger index were generated based on the historical fire location data. Finally, SFFPI was calculated by integrating all the mentioned static danger indices and categorized into 5 classes i.e., no fire, low, moderate, high and very high. MODIS TERRA satellite datasets such as Land Surface Temperature (MOD11A1) and Surface reflectance product (MOD09GA) to develop the Dynamic forest fire probability index. The parameters Land surface temperature (LST), Modified Normalized Difference Fire Index (MNDFI), Normalized Multiband Drought Index (NMDI) and Visible Atmospheric Resistant Index have been used to estimate the dynamic fire danger.

Fire danger index was generated by adding both the static and dynamic forest fire probability indices on the selected days of the fire season of Kazakhstan in the year 2017. The generated fire danger maps were overlaid by MODIS TERRA and AQUA active fire hotspots (MCD14) data to estimate the accuracy and it was ranging from $77.78 \%$ to $90.32 \%$ and the overall accuracy was estimated to be around $84.14 \%$. The fire danger index was tested for the years 2015 and 2016 and the accuracy was reasonably well ( $87 \%$ and $88 \%$ for 2015 and 2016 respectively), therefore, the fire danger index fairly predicting the fire danger over the study area.

In the year 2018, we started calculating fire danger index by using the MODIS TERRA Near Real Time satellite datasets i.e., MOD09GANRT, MOD11_L2, which are downloading from the ftp server. The generated fire danger maps have been uploading into the website (http://forest.gharysh.kz/) and updating every day. Thus, fire danger index was successfully developed for the country Kazakhstan.

Acknowledgments. Authors are grateful to Defense and Aerospace Ministry of Kazakhstan and Kazakhstan National Company for giving support during the research. The article presents the results obtained in the framework of the implementation of the scientific and technical program on targeted program financing of applied scientific researches in the field of space activities for 2018-2020 of the Aerospace Committee of the Ministry of Defense and Aerospace Industry of the Republic of Kazakhstan. The authors acknowledge the MODIS Science team for the Science Algorithms, the Processing Team for producing MODIS data, and the GES DAAC MODIS Data Support Team for making MODIS data available to the user community, NASA Earthdata team and FIRMS websites for free MODIS TERRA datasets and active fire data.

\section{References}

Abatzoglou, J.T. and Kolden, C.A. (2013). Relationships between climate and macroscale area burned in the western United States. International Journal of Wildland Fire, 22(7), 1003-1020. https:// doi.org/10.1071/WF13019

Adab, H.; Kanniah, K.D.; Solaimani, K. Modeling forest fire risk in the northeast of Iran using remote 194 sensing and GIS techniques. Natural hazards, 2013, 65(3), pp.1723-1743. https://doi.org/10. 1007/s11069-012-0450-8 
Alexander, M.E. and Cole, F.V. (2001). Rating fire danger in Alaska ecosystems. Fireline, 12, 2-3.

Alexander, M.E. and Fogarty, L.G. (2002). A pocket card for predicting fire behaviour in grasslands under severe burning conditions. Fire Technology, 25.

Allgöwer, B., Carlson, J.D., and Van Wagtendonk, J.W. (2003). Introduction to fire danger rating and remote sensing - will remote sensing enhance wildland fire danger rating? In Wildland Fire Dan-ger Estimation and Mapping: The Role of Remote Sensing Data (pp. 119).

Babu K.V.S., Roy, A., and Prasad, P.R. (2016a). Forest fire risk modeling in Uttarakhand Himalaya using TERRA satellite datasets. European Journal of Remote Sensing, 49(1), 381-395. https://doi. org/10. 5721/EuJRS20164921

Babu, K.V.S., Roy, A., and Prasad, P.R. (2016b). Developing the static fire danger index using geospatial technology. In Contemporary Computing and Informatics (IC3I), 2016 2nd International Conference, IEEE. 558-563. https://doi.org/10.1109/IC3I.2016.7918026

Babu, K.V.S.; Roy, A. and Prasad, R.P. (2018) Forest Fire Danger Index Based on Static and Dynamic Parameters Using Satellite Datasets. Preprints, https://doi.org/10.20944/preprints201803.0108. v1

Babu, K.V.S., Vanama, V.S.K., Roy, A., and Prasad, P.R. (2017, September). Assessment of forest fire danger using automatic weather stations and MODIS TERRA satellite datasets for the state Madhya Pradesh, India. In Advances in Computing, Communications and Informatics (ICACCI), 2017 International Conference on (pp. 1876-1881). IEEE.

Babu, S. and Agarwal, L. (2014). Forest fire danger model based on satellite datasets using geo-spatial techniques. International Journal of Advanced Scientific and Technical Research. 4. 106-118.

Bachmann, A. and Allgöwer, B. (2001). A consistent wildland fire risk terminology is needed. Fire Management Today, 61(4), 28-33.

Birch, D.S., Morgan, P., Kolden, C.A., Abatzoglou, J.T., Dillon, G.K., Hudak, A.T., and Smith, A.M.S. (2015). Vegetation, topography and daily weather influenced burn severity in central Idaho and western Montana forests. Ecosphere 6(1), 1-23. https://doi.org/10. 1890/ES14-00213.1

Bisquert, M., Caselles, E., Sánchez, J. M., and Caselles, V. (2012). Application of artificial neural networks and logistic regression to the prediction of forest fire danger in Galicia using MODIS data International Journal of Wildland Fire, 21(8), 1025-1029. https:// doi.org/10.1071/WF11105

Bisquert, M., Sánchez, J.M., and Caselles, V. (2014). Modeling fire danger in Galicia and Asturias (Spain) from MODIS images. Remote Sensing, 6(1), 540-554. https://doi.org/10.339 0 /rs6010540

Chandler, C., Cheney, P., Thomas, P., Trabaud, L., and Williams, D. (1983). Volume 1: Forest fire behavior and effects. Volume 2: Forest fire management and organization. Fire in Forestry. John Wiley \& Sons, Inc.

Chen, K., Blong, R., and Jacobson, C. (2001). MCE-RISK: integrating multicriteria evaluation and GIS for risk decision-making in natural hazards. Environmental Modelling \& Software, 16(4), 387397. https://doi.org/10.1016/S1364-8152(01) 00006-8

Chowdhury, E. H., and Hassan, Q. K. (2015). Development of a new daily-scale forest fire danger forecasting system using remote sensing data. Remote Sensing, 7(3), 2431-2448. https://doi.org/ $10.3390 /$ rs 70302431

Chuvieco, E., and Congalton, R.G. (1989). Application of remote sensing and geographic information systems to forest fire hazard mapping. Remote sensing of Environment, 29(2), 147-159. https:// doi.org/10.1016/0034-4257(89)90023-0

Chuvieco, E., and Salas, J. (1996). Mapping the spatial distribution of forest fire danger using GIS. International Journal of Geographical Information Science, 10(3), 333-345. https://doi.org/10.1080/02693

\section{2}

Chuvieco, E., Martin, M.P., and Palacios, A. (2002). Assessment of different spectral indices in the red-near-infrared spectral domain for burned land discrimination. International Journal of Remote Sensing, 23(23), 5103-5110. https://doi.org/10.1080/01431160210 153129

Chuvieco, E., Giglio, L., \& Justice, C. (2008). Global characterization of fire activity: toward defining fire regimes from Earth observation data. Global change biology, 14(7), 1488-1502.

De Groot, W.J., Field, R.D., Brady, M.A., Roswintiarti, O., and Mohamad, M. (2007). Development of the Indonesian and Malaysian fire danger rating systems. Mitigation and Adaptation Strategies for Global Change, 12(1), 165. https://doi.org/10.1007/s11027-006-90 43-8

Deeming, J.E. (1977). The National Fire-Danger Rating System, 1978 (No. 04; USDA, SD421 D4).

Earth Explorer. https://earthexplorer.usgs.gov/(accessed on May 26, 2018).

Earthdata. https://earthdata.nasa.gov/earth-observation-data-accessed on May 26, 2018.

EijiNunohiro, Katayama, K., Mackin, K.J., and Park, J.G. (2007). Forest and Field Fire Search System Using MODIS Data. JACIII, 11(8), 1043-1048. https://doi.org/10.20965/jaciii.2007. p1043

Flannigan, M.D., Stocks, B.J., and Wotton, B.M. (2000). Climate change and forest fires. Science of the total environment, 262(3), 221-229. https://doi.org/10.1016/S0048-9697(00)0052 4-6

Gitelson, A.A., Stark, R., Grits, U., Rundquist, D., Kaufman, Y. and Derry, D. (2002). Vegetation and soil lines in visible spectral space: a concept and technique for remote estimation of vegetation fraction. International Journal of Remote Sensing, 23: 2537-2562. https:// doi. org /10.1080/0143116011 0107806

Granström, A. (2001). Fire management for biodiversity in the European boreal forest. Scandinavian Journal of Forest Research, 16 (S3), 62-69. https://doi.org/10.1080/028275801 300090627

Hardy, C.C. (2005). Wildland fire hazard and risk: problems, definitions, and context. Forest Ecology and Management, 211(1-2), 7382. https://doi.org/10.1016/j.foreco.2005.01.029

Hernandez-Leal, P. A., Arbelo, M., and Gonzalez-Calvo, A. (2006). Fire risk assessment using satellite data. Advances in Space research, 37(4), 741-746. https://doi.org/10.1016/j.asr. 2004.12.053

IOL. (2010). Kazakhstan battles forest fires. https://www. iol.co.za/ news/world/kazakhstan-battles-forest-fires-680139. (Accessed on March 20, 2018).

Jaiswal, R.K., Mukherjee, S., Raju, K.D., and Saxena, R. (2002). Forest fire risk zone mapping from satellite imagery and GIS. International Journal of Applied Earth Observation and Geoinformation, 4(1), 1-10. https://doi.org/10.1016/S03032434(02) 00006-5

Kazakhstan International Security Exhibition. (2018). Forest fires in Kazakhstan up by $41 \%$, https://www.aips.kz/en/home/9-presscenter/news/137-forest-fires-in-kazakhstan-up-by-41, accessed on May 20, 2018.

Leblon, B., García, P.A.F., Oldford, S., Maclean, D.A., and Flannigan, M. (2007). Using cumulative NOAA-AVHRR spectral indices for estimating fire danger codes in northern boreal forests. International journal of applied earth observation and geoinformation, 9(3), 335342. https://doi. org/10.1016/j.jag.2006.11.001

Lee, B.S., Alexander, M.E., Hawkes, B.C., Lynham, T.J., Stocks, B.J., and Englefield, P. (2002). Information systems in support of wildland fire management decision making in Canada. Computers and Electronics in Agriculture, 37(1-3), 185-198. https://doi.org/10. 1016/S0168-1699(02)00120-5

LPDAAC, https://lpdaac.usgs.gov/dataset_discovery/modis/mod is_ products_table/mcd12q1. (accessed on Jan 20, 2018).

Maeda, E.E.; Arcoverde, G.F.; Pellikka, P.K.; Shimabukuro, Y.E. Fire 
risk assessment in the Brazilian 192 Amazon using MODIS imagery and change vector analysis. Applied Geography, 2011, 31(1), pp.7684. https://doi.org/10.1016/j. apgeog.2010.02.004

Matthews, S. (2009). A comparison of fire danger rating systems for use in forests. Australian Meteorological and Oceano- graphic Journal, 58(1), 41. https://doi.org/10.22499/2.5801.0 05

McArthur, A.G. (1967). Fire Behaviour in Eucalypt Forests.

Nieto, H., Sandholt, I., Aguado, I., Chuvieco, E., and Stisen, S. (2011). Air temperature estimation with MSG-SEVIRI data: Calibration and validation of the TVX algorithm for the Iberian Peninsula. Remote Sensing of Environment, 115(1), 107-116. https://doi.org/10. 1016 /j.rse.2010.08.010

Park, J., Yasuda, Y., and Sekine, H. (2006). Forest and fields fire monitoring system using MODIS data. In Japan Society of Photogrammetry and Remote Sensing Annual Conference.

Peterson, S.H., Roberts, D.A., and Dennison, P.E. (2008). Map- ping live fuel moisture with MODIS data: A multiple regression approach. Remote Sensing of Environment, 112(12), 4272-4284. https://doi.org/10.1016/j.rse.2008.07.012

Rothermel, R.C. (1983). How to predict the spread and intensity of forest and range fires. Dept of Agriculture Forest Service Intermountain Research Station, 143.

Roy, P.S. (2003). Forest fire and degradation assessment using satellite remote sensing and geographic information system. Satellite Remote Sensing and GIS Applications in Agricultural meteorology, 361.

Roy, P.S., Kushwaha, S.P.S., Murthy, M.S.R., Roy, A., Kushwaha, D., Reddy, C.S., and Singh, S. (2012). Biodiversity chara- cterisation at landscape level: National assessment, Indian Institute of Remote Sensing, Dehradun, India.

San-Miguel-Ayanz, J., Carlson, J. D., Alexander, M., Tolhurst, K., Morgan, G., Sneeuwjagt, R., and Dudley, M. (2003). Current methods to assess fire danger potential. Wildland Fire Danger Estimation and Mapping: The Role of Remote Sensing Data pp. 21-61. https://doi.org/10.1142/9789812791177_0002

Schneider, P., Roberts, D.A., and Kyriakidis, P.C. (2008). A VARIbased relative greenness from MODIS data for computing the Fire Potential Index. Remote Sensing of Environment, 112(3), 1151-1167. https://doi.org/10.1016/j.rse.2007. 07.010

SEDAC. http://sedac.ciesin.columbia.edu/data/set/wildareas-v2-human-influence-index-geographic/data-download (accessed 21, December, 2017.

Sow, M., Mbow, C., Hély, C., Fensholt, R., and Sambou, B. (2013). Estimation of herbaceous fuel moisture content using vegetation indices and land surface temperature from MODIS data. Remote Sensing, 5(6), 2617-2638. https://doi.org/10.33 90/rs5062617
Stow, D., Niphadkar, M., and Kaiser, J. (2005). MODIS-derived visible atmospherically resistant index for monitoring chaparral moisture content. International Journal of Remote Sensing, 26(17), 3867-3873. https://doi.org/10.1080/01431160 500185342

Taylor, S.W., and Alexander, M.E. (2006). Science, technology, and human factors in fire danger rating: The Canadian experience. International Journal of Wildland Fire, 15(1), 121-135. https:// doi.org/10.1071/WF05021

Vadrevu, K.P., Badarinath, K.V.S., and Anuradha, E. (2008). Spatial patterns in vegetation fires in the Indian region. Environmental monitoring and assessment, 147(1-3), 1. https://doi.org /10.1007/s 10661-007-0092-6

Van Nest, T.A. and Alexander, M.E. (1999). Systems for rating fire danger and predicting fire behavior used in Canada. In Actas de National Interagency Fire Behavior Workshop, 1.

Van Wagner, C.E., and Forest, P. (1987). Development and Structure of the Canadian Forest Fire Weather Index System. Forest Technical Report 35. Canadian Forest Service, Ottawa, Ontario.

Vermote, E.F., El Saleous, N.Z., and Justice, C.O. (2002). Atmospheric correction of MODIS data in the visible to middle infrared: first results. Remote Sensing of Environment, 83(1-2), 97-111. https:// doi.org/10.1016/S0034-4257(02)0008 9-5

Viegas, D.X., Bovio, G., Ferreira, A., Nosenzo, A., and Sol, B. (1999). Comparative study of various methods of fire danger evaluation in southern Europe. International Journal of wildland fire, 9(4), 235246. https://doi.org/10.1071/WF00015

Vilar L., Camia A., and San-Miguel-Ayanz J. (2015). A comparison of remote sensing products and forest fire statistics for improving fire information in Mediterranean Europe. European Journal of Remote Sensing, 48, 345-364. https://doi.org/10.5721/EuJRS2015 4820

Wang, L. and Qu, J.J. (2007). NMDI: A normalized multi-band drought index for monitoring soil and vegetation moisture with satellite remote sensing. Geophysical Research Letters, 34(20). https://doi.org/10.1029/2007GL031021

Wang, L. and Qu, J.J. (2009). Satellite remote sensing appl- ications for surface soil moisture monitoring: A review. Frontiers of Earth Science in China, 3(2), 237-247. https://doi.org/10.1007/s11707009-0023-7

Wang, L., Qu, J.J., and Hao, X. (2008). Forest fire detection using the normalized multi-band drought index (NMDI) with satellite measurements. Agricultural and forest meteorology, 148(11), 1767-177 6. https://doi.org/10.1016/j.agrformet.2008. 06.005

Willis, C., van Wilgen, B., Tolhurst, K., Everson, C., D'Abreton, P., Pero, L., and Fleming, G. (2001). The development of a national fire danger rating system for South Africa. Department of Water Affairs and Forestry, Pretor. 